\title{
Edmodo and Schoology Application in Mathematics Learning in Elementary School
}

\author{
Y Ariani ${ }^{1}$, Y Helsa ${ }^{2}$ \\ Universitas Negeri Padang, Jl. Prof Dr. Hamka Air Tawar, Padang, Indonesia ${ }^{1,2}$ \\ \{yettiariani@fip.unp.ac.id\}
}

\begin{abstract}
This article aims to determine the effectiveness of learning by including teaching material on the Edmodo and schoology application towards learning outcomes in fourth-grade elementary schools. Research data were collected quantitatively with experimental research using pre-experimental methods. Based on data analysis, the results of hypothesis testing using the t-test (t-test) were 12.03 and at the real level $\alpha=0.05$ thus t-count $>$ t-table then $\mathrm{H} 1$ was accepted and H0 was rejected. There are differences in learning outcomes between students who use the Edmodo application before and after teaching material is given. Thus, the results show that Edmodo applications incorporated into teaching materials are more effectively used towards learning outcomes.
\end{abstract}

Keywords: Elementary School, Edmodo, Schoology, Mathematics Learning

\section{Introduction}

The effectiveness of learning is learning that allows students to learn easily, fun, and can achieve learning goals following the expectations of a teacher [1] [2] [3] [4]. The effectiveness is related to the success of learning implementation designed by the teacher to achieve learning objectives [5] [6]. The effectiveness of learning has seven indicators namely 1) good preparation of learning, 2) effective communication, 3) mastery and enthusiasm in learning, 4) positive attitude towards students, 5) giving tests and fair grades, 6) flexibility in teaching approaches, 6) Learning in the digital era 7) Good student learning outcomes [7]. The crucial point here is learning in the digital era. This is following the development of the world community towards industry 4.0. Industry 4.0 influences all aspects of the world community [8] [9] [10]. One of the impacts is in the learning process [11] [12]. The industry 4.0 demands a change of traditional learning process into the technology-based learning system. It means that teachers in the learning process must change conventional learning into digital learning using technology. The use of technology can be observed from the way teachers teaching and using technology in the classroom.

The use of technology has begun to be implemented by the teacher. In 2000, teachers only used a blackboard in learning but now they are relatively using projector media such as computers, laptops, smartphones, and so on. Besides, we can see that students use smartphones, tablets, and computers more often because an online network system can provide all things students wish to play with. The survey of Indonesian Internet Service Providers Association (APJII) stated that internet users in Indonesia in 2017 were 143 million 
and $49.2 \%$ of them were students and teachers [13]. Also, Puspita's research (mentioning that internet usage in children between the ages of 6 and 12 was conducted in Surabaya and $12 \%$ of children in the age of five were familiar with the internet, and $45 \%$ of these children claimed to know the internet from their parents, and $51 \%$ of them use internet at home and $51.7 \%$ at private space. Consequently, this situation influences children to make their own decisions in interpreting the content on the website [14].

This fact gives positive and negative impacts. The negative impact is that without direct internal supervision by adults will give opportunities for students to access information out of their needs thus it will influence students' mindset and behavior. While the positive impact is that students already have skills in using technology. Therefore, the teacher as a facilitator in improving students ability must make advantages and disadvantages in internet-based technology used as an innovation in the learning process. One learning innovation used as a solution is to incorporate the internet-based technology usage in the learning process by using Edmodo application [15]. This includes learning mathematics in elementary school.

Mathematics is abstract but applicable learning [16]. Therefore, teachers must connect the mathematics learning process with the condition of elementary school students. Elementary school students are in a concrete operational period [17]. That is why the connection between students' thinking process with mathematics learning characteristic is needed. Therefore, Edmodo is expected to facilitate this. Edmodo is one type of communication and information technology in the form of text, images or sound in social networking websites used for learning process thus it facilitates the learning process for teachers, students, and parents [18]. Edmodo is a social networking learning platform for teachers, students, and parents, and it is designed to make students eager to learn in a more familiar environment that will impact the achievement of learning goals [19]. Edmodo application has several advantages, namely easy to send files, images, videos, and links; send individual messages to teachers; create groups for individual discussion according to specific classes or topics; a safe environment for new students because the messages are designed to be easily understood [20].

Based on observation, Edmodo application has been implemented in Al-Azhar Elementary School in Bukittinggi. Edmodo application has not implemented optimally at this school. This is because teachers only use Edmodo as assigning tasks and homework, whereas in learning they must begin with learning material first, then followed by assigning assignments and homework. A teacher should try to include learning material in Edmodo application thus the effectiveness of learning using Edmodo application can be seen before and after input it in teaching material. Therefore the purpose of this study is to determine the effectiveness of mathematics learning using Edmodo for elementary school students

\section{Method}

This research is a quantitative study with experimental research using the pre-experimental method. The population in this study is the 4th grade of Al-Azhar elementary school in Bukittinggi. Then, the sample was taken using the Purposive Sampling technique and the researcher only took one class at the end, namely the 4th grade $\mathrm{C}$. This is because the class had conditions and criteria consistent with the research conducted. The instrument used was a multiple-choice test. The test was conducted at the beginning (pretest) and the final (posttest) to see student learning outcomes. The instruments have been arranged thus the quality is guaranteed, and then the instruments are tested first before finally being used for research. After that, the questions are tested to find out whether it can be used, revised, or discarded. 
Then, a pre-test and post-test conducted using a t-test of two small samples interconnected to obtain differences in learning outcomes between students learning using the Edmodo application before and after inserted in learning material. Finally, the data shows that the learning outcome is at a real level of 0.05 .

\section{Result and Discussion}

The data collection in this study was carried out by conducting a pre-test in advance to obtain preliminary data about students' understanding regarding material with and without Edmodo application. After carrying out the pre-test, the treatment given by inserting teaching data presentation material into the Edmodo application. The treatment was carried out in 2 meetings with the time allocation was $3 \times 35$ minutes. After being given treatment, a post-test given to obtain data on student understanding regarding the material. From the pre-test conducted in the experimental class, it was found that 3 students got 33 scores, 4 students got 40 scores, 2 students got 53 scores, 3 students got 60,2 students got 73 and 1 student got 80 . Hence they obtained an average value of 50.76. While from the post-test, 2 students got 60,1 student got 66,3 students got 73, 5 students got 86,4 students got 93 and 2 students got 100 . Hence the average value is 82.76 . Based on the measurements above, there are differences in the acquisition of learning outcomes before and after attaching teaching material on the Edmodo application.

Based on an analysis of research data the t-test formula obtained is 12.03 , with the test criteria $\mathrm{dk}=1$ in the table of significance $0.05=2.12$ or can be written $12.30>2.12$. This means that the working hypothesis (H1) is accepted and the null hypothesis (H0) is rejected. Thus, including teaching material on Edmodo application shows its real effectiveness. Consequently, learning outcomes increase.

Besides, students show activeness during Edmodo learning process. For example, students ask a lot of questions, students are active in completing tasks and uploading assignments, and students show activity in the presentation process. This is because Edmodo provides a new forum for students to carry out the learning process under their conditions. Also, Edmodo can provide motivational motivation thus students gradually learn information actively [21] [22]. Edmodo can improve learning outcomes because Edmodo gives a variety of learning resources. Therefore, students find references that match their characteristics. Edmodo facilitates various templates for uploading learning resources. Learning resources can be in PDF, PPT, Link, or video [23]. This is one of the factors students successfully find the information they want to know. Edmodo also can interact with the internet and its use, for example doing tasks by utilizing the existing application on a laptop and uploading them to Edmodo. Subsequently, this is additional learning loved by students because Edmodo can facilitate students to connect to the internet [24] [25].

Edmodo facilitates multi-directional communication between students and teachers and fellow students. Communication in Edmodo media allows the unlimited exchange of information [26]. Communication that occurs in a multi-directional way can support students to receive and give information. Besides, Edmodo is an application that can be accessed anywhere and anytime. This makes it possible for students to access learning anytime and anywhere. Students can repeat the understanding of the material as long as they are connected to the internet. 


\section{Conclusion}

Based on the results, after analyzing and discussing the problems, hypothesis testing using t-test with a significant level $\alpha=0.05$ is 12.30 and t-count $>$ t-table $(0,05)(16)$ therefore $\mathrm{H} 1$ in this study was accepted and $\mathrm{H} 0$ was rejected. There are differences in the acquisition of learning outcomes before and after attaching teaching material on Edmodo application for the 4th grade of Al-Azhar Elementary School in Bukittinggi. Thus it can be concluded that the Edmodo application is effectively used on the learning outcomes of data presentation.

\section{Acknowledgment}

Thank you to Univesitas Negeri Padang for facilitating this research. Also, I would like to thank Al-Azhar Elementary School in Bukittinggi for the permission given in conducting this research

\section{References}

[1] J Hackathorn, E D Solomon, K L Blankmeyer, R E Tennial and A M Garczynski 2011 Journal of Effective Teaching 1140

[2] D Lucardie 2014 Procedia-Social and Behavioral Sciences 142440

[3] F Bavi 2018 Journal of Language Teaching and Research 9630

[4] A Paolini 2015 Journal of Effective Teaching 1520

[5] M J Kintu, C Zhu and E Kagambe 2017 International Journal of Educational Technology in Higher Education 147.

[6] J Dunlosky, K A Rawson, E J Marsh , M J Nathan and D T Willingham 2013 Psychological Science in the Public Interest 144

[7] Istarani and I Pulungan 2015 Ensiklopedia Pendidikan (Medan: CV Iscom Medan)

[8] Y Liao, E R Loures, F Deschamps, G Brezinski and A Venâncio 2018 Production 281

[9] R Morrar,H Arman and S Mousa 2017 Technology Innovation Management Review 7 12

[10] J Nagy, J Oláh, E Erdei, D Máté and J Popp 2018 Sustainability 103491

[11] A Benešová and J Tupa 2017 Procedia Manufacturing 112195

[12] A Afrianto 2018 English Language Teaching and Research 21

[13] APJII 2017 Saatnya Jadi Pokok Perhatian Pemerintah dan Industri (Jakarta: APJII)

[14] E M Husni and A Fatulloh 2016 Jurnal Fakultas Hukum UII E6 e16

[15] K Balasubramanian, V Jaykumar and L N Fukey 2014 Procedia-Social and Behavioral Sciences 144416

[16] A K Kenedi, Y Helsa, Y Ariani, M Zainil and S Hendri 2019 Journal on Mathematics Education 1069

[17] A Kiswanto 2017 Adv. Soc. Sci. Educ. Humanit. Res 1181040

[18] F Al-Kathiri 2015 English Language Teaching 8189

[19] P Purnawarman, S Susilawati, W Sundayana 2016 Indonesian Journal of Applied Linguistics 5242

[20] U B U BV 2016 Eksis 123295

[21] S Charoenwet and A Christensen 2016 Imsci 2016297

[22] K M Al-Said 2015 Turkish Online Journal of Educational Technology-TOJET 14167 
[23] B Basori 2013 Jurnal Ilmiah Pendidikan Teknik dan Kejuruan 698

[24] C Holland and L Muilenburg 2011 Society for Information Technology \& Teacher Education International Conference vol 1(Chesapeake/AACE) p. 3232

[25] T Yagci 2015 International Visible Conference on Educational Studies and Aplied Linguistics vol 6 (Irak/IVCESAL) p. 436

[26] M Thongmak 2013 Journal of e-Learning and Higher Education 20131 